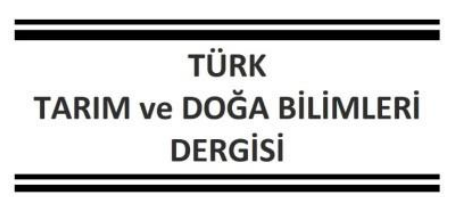

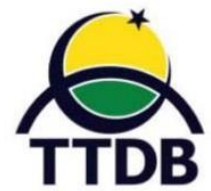

www.dergipark.gov.tr/turkjans

\title{
Yulaf Genetik Haritalama Popülasyonu Ogle1040/Tam 0-301'in Yağ İçeriği ve Yağ Asidi Kompozisyonlarının Belirlenmesi
}

\author{
Hilal KARAKUZULU ${ }^{1}$, Ali TEKIN $^{2}$, Ziya DUMLUPINAR ${ }^{1^{*}}$ \\ 1,3Kahramanmaraş Sütçü Imam Üniversitesi Ziraat Fakültesi Tarımsal Biyoteknoloji Bölümü, Kahramanmaraş \\ ${ }^{2}$ GAP Uluslararası Tarımsal Araştırma ve Eğitim Merkezi Müdürlüğü, Diyarbakır \\ *Sorumlu Yazar: zdumlupinar@ksu.edu.tr
}

Geliş Tarihi: 02.04.2021 Düzeltme Geliş Tarihi: 22.06.2021 Kabul Tarihi: 01.07.2021

\section{Öz}

Bu çalışma, Ogle1040/Tam 0-301 yulaf genetik haritalama popülasyonuna ait 136 hat ve ebeveynlerin yağ içeriği ve yağ asidi kompozisyonunu belirlemek amacıla Kahramanmaraş koşullarında yürütülmüştür. Yulaf bitkisinde genetik haritalama yapabilmek amacıyla oluşturulan Ogle1040/Tam 0-301 popülasyonunda bugüne kadar birçok fenotipik özellik incelenmiştir ve bu özellikler genotipik datalarla ilişkilendirilmiştir. Çalışmada, Ogle1040/Tam 0-301 popülasyonun ve ebeveynlerinin yağ içeriği ve yağ asidi kompozisyonlarının (palmitik asit, stearik asit, oleik asit, linoleik asit, alfa-linolenik asit, lignoserik asit, nervonik asit, myristik asit, palmiteloik, gama-linolenik, dihomo-gama-linolenik asit, heneikosanoik asit, behenik asit ve laurik asit) incelenmesi amaçlanmıştır. Araştırma sonuçlarına göre, Ogle1040 çeşidinin yağ içeriği \% 4.82 olurken, TAM 0-301 çeşidinin yağ içeriği ise \% 5.54 olmuştur. Ogle1040/Tam 0-301 popülasyonunda ise yağ içeriği \% 2.65 ile 5.89 değerleri arasında değişmiştir. Ogle1040/Tam 0-301 popülasyonuna ait 136 hat ve ebeveynlere ait ortalama yağ içeriği \% 4.89 olarak saptanmıştır. Yulafta en temel bulunan yağ asitlerinin linoleik, oleik ve palmitik asitler olduğu sonucuna ulaşılmışır Palmitik asit bakımından OT42, OT98 ve OT84 (\% 28.05, 25.24 ve 24.25) en yüksek değerleri alırken, Oleik asit bakımından OT2, OT16 ve OT63 (\% 41.94, 40.99 ve 39.29) öne çıkmış ve linoleik asit bakımından da OT129, OT111 ve OT133 (\% 49.74, 46.36 ve 46.01) genotipleri diğer hatlardan yüksek değerlere sahip olmuştur. Bu sonuçlara göre, genotipler yağ oranı, stearik asit, oleik asit, nervonik asit, palmiteloik asit, ve laurik asit özelliklerine göre normal dağılıma yakın bir dağıım göstermişler ve bu çalışmada elde edilen bu verilerin kantitatif özelliklerin kromozomlar üzerinde bulunduğu yerlerin tespit edilmesi (QTL) bakımından kullanılabileceği anlaşılmıştır.

Anahtar kelimeler: Yulaf, yağ içeriği, yağ asidi kompozisyonu, genetik haritalama popülasyonu, kantitatif özellikler

\section{Determination of Oil Content and Fatty Acid Composition of Oat Genetic Mapping Population Ogle 1040 / TAM 0-301}

\begin{abstract}
This study was carried out to determine oil content and fatty acid composition of 136 lines belonging to Ogle1040/Tam 0-301 oat genetic mapping population and the parents under Kahramanmaras conditions. The Ogle1040/Tam 0-301 population which was created to construct genetic mapping in oat crop, to date many phenotypical traits were investigated and those traits were related with the genotypic data. In the research, it is aimed to investigate fatty acid content and fatty acid compositions (palmitic acid, stearic acid, oleic acid, linoleic acid, alfa-linolenic acid, lignoseric acid, nervonic acid, myristic acid, palmiteloic acid, gamalinolenic acid, dihomo-gama-linolenic acid, heneicosanoic acid, behenic acid and lauric acid) of the Ogle1040/Tam 0-301 population and the parents. According to the results, the fat content of the Ogle1040 cultivar was $4.82 \%$, while the fat content of TAM 0-301 was 5.54\%. The fatty acid content of the Ogle1040/Tam 0-301 population varied from 2.65 to $5.89 \%$. The average fat content of 136 lines and the parents belonging to Ogle1040/Tam 0-301 were determined as $4.89 \%$. It was concluded that the main fatty acids of lipids in oats are linoleic, oleic, and palmitic acids. In terms of palmitic acid OT42, OT98 and OT84 (28.05, 25.24 and 24.25\%) had
\end{abstract}


higher ratios while, OT2, OT16 and OT63 (41.94, 40.99 and 39.29\%) was higher for oleic acid and OT129, OT111 and OT133 (49.74, 46.36 and 46.01\%) genotypes were the highest for linoleic acid. In addition, it was concluded that the genotype was effective on the fat and fatty acid composition of the oat grain. Based on the results, genotypes showed a normal distribution for fat content, stearic acid, oleic acid, nervonic acid, palmiteloic acid and lauric acid traits and it is understood that the data obtained from this research could be used for determination of quantitative traits (QTL) on chromosomes.

Key words: Oat, fat content, fatty acid composition, genetic mapping population, quantitative traits.

\section{Giriş}

Yulaf (Avena sativa L.), dünyada insan beslenmesinde ve hayvan yemi olarak kullanılan bir tahıl bitkisidir (Hoffmann, 1995; Peterson ve ark., 2005). Kültürü yapılan yulaf hekzaploid $(2 n=6 x=42)$ olup Avena sativa L. ve Avena byzantina Coch. türlerini kapsamaktadır.. Yulaf diğer tahıllarla kıyaslandığında daha marjinal alanlarda yetiştirilebilmektedir (Hoffmann, 1995; Ren ve ark., 2007).

Yulaf öncelikle atları beslemek amacıyla kullanılan bir ürün olarak ön plana çıkmıştır ancak aynı zamanda gıda üretimi için ham materyal, eczacilıkta hammadde ve biyomateryal olarak kullanılmaktadır (Fan ve ark. 2004). Yulafın insan sağlığı üzerindeki olumlu etkilerinden dolayı son zamanlarda yulaf tüketimine olan ilgi artmıştır. Yulaf ve yulaf bazlı ürünleri tüketen insanların serum kolesterolü ve diğer kardiyovasküler hastalık risklerinin azalması, kanser diyabet ve gastrointestinal bozuklukların önlenmesi yulafın sağlık üzerindeki olumlu etkileri ile bağdaştırılmıştır (Gangopadhyay ve ark., 2015; Grundy ve ark., 2018).

Yulaf diğer tahıllar ile kıyaslandığında toplam protein, ham yağ, diyet lifi (nişasta olmayan), antioksidanlar, vitaminler, amino asit kompozisyonu ve mineral içeriği bakımından daha avantajlıdır (Sangwan ve ark., 2014). İnsan beslenmesinde yulaf tanesinin protein ve çözülebilir lif ( $\beta$-glukan) oranının yüksek, yağ oranın ise düşük olması istenmektedir. Hayvan beslenmesinde kullanılan yulaf tanesinin ise insanlar için istenilen düşük yağ, yüksek $\beta$-glukan oranlarının aksine maksimum enerji sağlaması için protein ve yağ oranının yüksek, $\beta$-glukan oranının ise düşük olması istenmektedir (Peterson ve ark., 2005).

Yulaf tanesinin sahip olduğu yağ içeriği \% 2'den \% 18'e kadar geniş bir aralıkta değişim göstermektedir (Frey ve Holland, 1999; Halima ve ark., 2015). Yulafın sahip olduğu bu yüksek yağ içeriğinin yaklaşık \% 75'nin doymamış yağ asitlerinden (palmitik, oleik ve linoleik) meydana gelmesi onu diğer tahıllardan farklı kılmaktadır (Kan, 2015). Toplam yağ içeriği ve endospermde lipit biriktirme yeteneği genotipten güçlü bir şekilde etkilenmektedir (Thro ve ark.,1985). Doehlert ve ark., (2001), yulaf tanelerinin sahip olduğu yağ içeriğinin çevre faktörlerinden daha az etkilendiğini yağ içeriği üzerinde genetik farklılığın daha etkili olduğunu belirtmişlerdir.

Yulaf bitkisinin genomunun haritalanabilmesi ve tarımsal özelliklerle genetik özelliklerin karşılaştırılabilmesi ve interaksiyonlarının ortaya çıkarılabilmesi için model bitki popülasyonları geliştirilmiştir. Bu popülasyonlardan bir tanesi de Ogle1040/Tam O301 popülasyonudur (Dumlupınar ve ark., 2019). Bu popülasyon Amerika Birleşik Devletlerinde bu iki ebeveyn melezlenerek elde edilmiş ve kendilenerek $F_{8}$ durumuna getirilmiştir (Portyanko ve ark., 2001). Bu çalışmanın amacı, Ogle1040/Tam 0-301 popülasyonuna ait 136 adet genotip ve ebeveynlerin yağ ve yağ asitleri kompozisyonlarını karakterize etmektir.

\section{Materyal ve Metot}

Çalışmada, Portyanko ve ark., (2001)'in geliştirdiği yulaf genetik haritalama popülasyonu Ogle1040/Tam 0-301 popülasyonuna ait 136 hat ve ebeveynleri (Ogle1040 ve Tam 0-301) materyal olarak kullanılmıştır.

Bu çalışma 2012-2013 ürün yetiştirme sezonunda Kahramanmaraş koşullarında yürütülmüştür. Ekim işlemi 1 metre uzunluğundaki tek sıralara metrekareye 350 tane gelecek şekilde yapılmıştır. Ekimle birlikte $60 \mathrm{~kg} / \mathrm{ha} \mathrm{N}$ ve $60 \mathrm{~kg} / \mathrm{ha}$ $\mathrm{P}_{2} \mathrm{O}_{5}$ kardeşlenme döneminde ise üst gübre olarak $80 \mathrm{~kg} /$ ha N gübresi kullanılmıştır. Geniş yapraklı yabancı otlar ile mücadele etmek için herbisit (Tribenuron-methyl \% 75) kullanılmıştır. Hasat yulaf hatları olgunlaştıkça orak ile yapılmış ve başak harman makinası ile patoz edilerek taneler elde edilmiştir.

Yulaf genetik popülasyonuna ait hatlar ve ebeveynleri orakla biçilerek, başak harman makinasında harmanlanmıştır. Araştırmada, tek bitki sıralarına ekilen yulaf hatlarından ve ebeveynlerden elde edilen tohumlar öğütülerek Soxhlet metoduyla yağ içeriğine bakılmıştır (Soxhlet, 1879). Yağ asitleri (palmitik asit, stearik asit, oleik asit, linoleik asit, alfa-linolenik asit, lignoserik asit, nervonik asit, myristik asit, 
palmiteloik, gama-linolenik, dihomo-gama-linolenik asit, heneikosanoik asit, behenik asit ve laurik asit) analizleri metil-esterleşme ve standart hazırlama işleminden sonra Shimadzu marka gaz kromatografi (GC) cihazında yapılmıştır (Robert ve ark., 2004).

Yağ ve yağ asidi kompozisyonlarına ait Histogramlar MS Excel yazılımı kullanılarak oluşturulmuştur. Yağ içeriği, palmitik asit, oleik asit ve linoleik asit değerlerine ait Z-skoru değerleri Iverson (2011)'in belirtiği formül (Eşitlik 1) ile hesaplanmış ve web-tabanlı bir uygulama ile Pdeğerleri (https://goodcalculators.com/p-valuecalculator/?pinpt=-7\&tpval=2).

$$
Z-S k o r u=\frac{x-\mu}{\sigma}
$$

$z$ standart skor; $x$ ebeveyn ortalaması; $\mu$ deneme ortalaması; ve $\sigma$ örneğin standart sapması.

\section{Bulgular ve Tartışma}

İdeal bir QTL haritalama çalışmasında incelenen özelliklerin normal dağılım göstermesi beklenmektedir. Normal dağılımdan sapmalar, QTL tespitlerinin doğruluğunu etkileyebilmekte ve yanlış QTL tespitlerine neden olabilmektedir. Araştırmada incelenen özelliklere ait veri dağılımları sonraki QTL çalışmalarında kullanılmak üzere histogramlar kullanılarak değerlendirilmiştir. Bunlardan yağ içeriği ve toplam yağ içeriğinin yaklaşık \% 75'ini oluşturan doymamış yağ asitleri palmitik, oleik ve linoleik asitlere (Sunulu, 2021) ait tanımlayıcı istatistikler Çizelge $1^{\prime}$ de verilmiştir.

Çizelge 1. Yağ içeriği ve bazı doymamış yağ asitlerine ait tanımlayıcı istatistikler.

\begin{tabular}{|c|c|c|c|c|}
\hline & Yağ içeriği & Palmitik Asit & Oleik Asit & Linoleik Asit \\
\hline Ebeveyn Ortalaması & 5,18 & 19,28 & 32,53 & 39,96 \\
\hline Deneme Ortalaması & 4,89 & 18,48 & 30,88 & 38,43 \\
\hline Standart Sapma & 0,981 & 2,447 & 5,435 & 5,276 \\
\hline Z-Skoru & 0,295 & 0,326 & 0,303 & 0,289 \\
\hline P-Değeri & $0,38^{\text {öd }}$ & $0,37^{\text {od }}$ & $0,38^{\text {öd }}$ & $0,38^{\text {öd }}$ \\
\hline
\end{tabular}

öd İstatistiki olarak önemli değil

Yulaf genetik haritalama popülasyonu Ogle1040/Tam 0-301 popülasyonuna ait 136 hat ve ebeveynlere ait yağ oranları Şekil 1'de histogram olarak verilmiştir. Yağ analizi sonuçlarına göre, Ogle1040 \% 4.82 yağ oranına sahip olurken, Tam 0-301 ise \% 5.54 yağ oranına sahip olmuştur. Ogle1040/Tam 0-301 popülasyonuna ait 136 hat ve ebeveynlere ait ortalama yağ içeriği \% 4.89 olarak saptanmıştır. Popülasyonu oluşturan genotiplerin 20 tanesi en yüksek yağ oranı değerini almıştır (\% 6.29). Diğer genotipler ise genel olarak \% 2.65 ile \% 5.89 oranında yağ içeriğine sahip olmuşlardır (Şekil 1). Saastamoinen ve ark., (1989), yulaf genetik kaynaklarında yağ oranlarının \% 6.1 ile \% 7.8 arasında olduğunu saptamışlardır. Bununla birlikte Welch ve ark., (2000), yaptıkları çalışmada üç yulaf türüne ait (A. agadiriana, A. atlantica ve A. damascena) yağ oranının \% 4.2 ile \% 10.6 arasında olduğunu saptamışlardır. Sterna ve ark., (2016) yulaf yağ içeriğini \% 5.20 ile \% 12.40 arasında hesaplamışlardır. Yulaf tanesinin yağ içeriği \% 2'den \% 18'e kadar geniş bir aralıkta değişim göstermektedir (Frey ve Holland, 1999; Halima ve ark., 2015). Yulaf tanesinin sahip olduğu yağ içeriği üzerinde genotip ve çevrenin birlikte etki ettiğini gösteren birçok çalışma vardır (Mut ve ark., 2018; Bağcl ve ark., 2019; Erbaş Köse ve ark., 2020). Bununla birlikte yulaf tanesinin yağ içeriği üzerinde genotipin çevreden daha etkili olduğunu bildiren çalışmalarda vardır (Doehlert ve ark., 2001; Dhanda, 2011; Carlson ve ark., 2019). 


\section{Yağ Oranı (\%)}

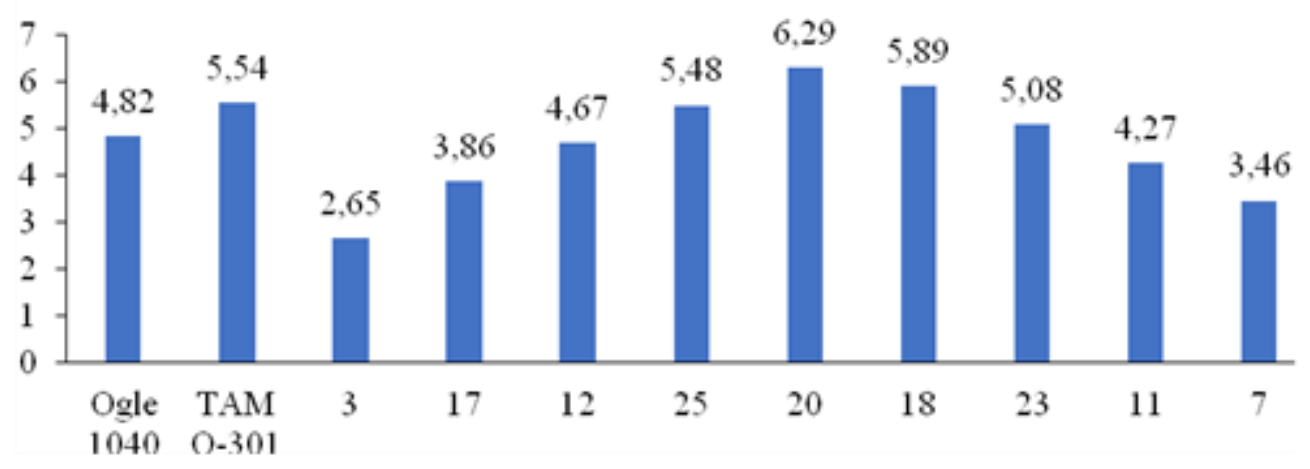

Şekil 1. Ogle1040/ TAM 0-301 popülasyonu yağ oranına ait histogram.

Çalışmamızda kullandığımız yulaf genetiklerinin sahip olduğu yağ içeriği çok geniş bir aralıkta değişim göstermektedir ve araştırma sonuçlarımız önceki çalışmalarda uyuşmaktadır. Ogle1040/Tam 0-301 popülasyonuna ait 136 hat ve ebeveynlere ait doymamış yağ asitleri içeriklerine ait histogramlar Şekil 2'de verilmiştir. Oleik asit analizi sonuçlarına göre, Ogle1040\% 31.35 , Tam 0-301 ise \% 33.70 oranında oleik aside sahip olmuştur. Popülasyonu oluşturan genotiplerin 9 tanesi en yüksek yağ asidi oranı değerine (\% 41.45) sahip olurken popülasyonun büyük çoğunluğu \% 26.69 ile \% 38.13 oleik aside sahip olmuştur. Ogle1040/Tam 0-301 popülasyonuna ait 136 hat ve ebeveynlere ait ortalama oleik asit oranı \% 29.19 olduğu tespit edilmiştir. Linoleik asit analizi sonuçlarına göre, Ogle1040 \% 40.72 linoleik asidi oranına sahip olurken, Tam 0-301 ise \% 39.19 oranına sahip olmuştur. Popülasyonu oluşturan genotiplerin 9 tanesi \% 49 ile en yüksek yağ asidi oranı sahip olmuştur. Genotiplerin büyük çoğunluğunun (112) sahip olduğu linoleik asit değeri \% 36.17-45.22 arasında değişiklik göstermiştir. En düşük linoleik asit içeriğine sahip 13 genotip ise \% 3-13.57 arasında değişim göstermiştir (Şekil 2). Ogle1040/Tam 0-301 popülasyonuna ait 136 hat ve ebeveynlere ait ortalama linoleik asit oranı \% 35.77 olduğu saptanmıştır. Palmitoleik asit analizi sonuçlarına göre, Ogle1040 \% 0.26 palmitoleik asidi oranına sahip olurken, Tam 0-301 ise \% 0.20 oranına sahip olmuştur. Popülasyonu oluşturan genotiplerden 31 tanesinde palmitoleik aside rastlanmamıştır. OT102 genotipi en yüksek palmitoleik aside (\% 0.67) sahip olurken diğer genotipler ise genel olarak \% 0.11 ile \% 0.52 oranında değişim göstermiştir. Ogle1040/Tam O301 popülasyonuna ait 136 hat ve ebeveynlere ait ortalama linoleik asit oranı \% 0.19 olarak saptanmıştır (Şekil 2). Ogle1040 ve Tam 0-301 ebeveynlerinin araşidonik asit içeriği sırasıyla \% 1.81 ve \% 0.69 olarak tespit edilmiştir. 38 tane genotipe ait araşidonik asit içeriğine rastlanılmazken 1 genotip ise \% 19.33 en yüksek içeriğe sahip olmuştur. Ogle1040/Tam 0-301 popülasyonuna ait 136 hat ve ebeveynlere ait ortalama araşidonik asit oranı \% 1.46 olarak belirlenmiştir (Şekil 2). Nervonik asit analizi sonuçlarına göre, Ogle1040 ebeveyninde \% 0.27 nervonik asit oranı bulunurken, Tam 0-301 ise \% 0.67 oranına sahip olmuştur. Popülasyonu oluşturan genotiplerin çoğunluğu ebeveynlerin sahip olduğu içeriğe yakın değerler arasında kaldığı gözlemlenmiştir (Şekil 2). Ogle1040/Tam 0-301 popülasyonuna ait 136 hat ve ebeveynlere ait ortalama nervonik asit oranı \% 0.24 olarak belirlenmiştir. Gama-linolenik asit analizi sonuçlarına göre, Ogle1040 \% 0.14 gama-linolenik asidi oranına sahip olurken, Tam 0-301 ise \% 0.15 oranına sahip olmuştur. Popülasyonu oluşturan genotiplerden 41 tanesinde gama-linolenik aside rastlanmazken 95 genotip ise ebeveynlerinden oldukça yüksek (\% 1.01-11.06) içeriğe sahip olduğu görülmüştür (Şekil 2). 

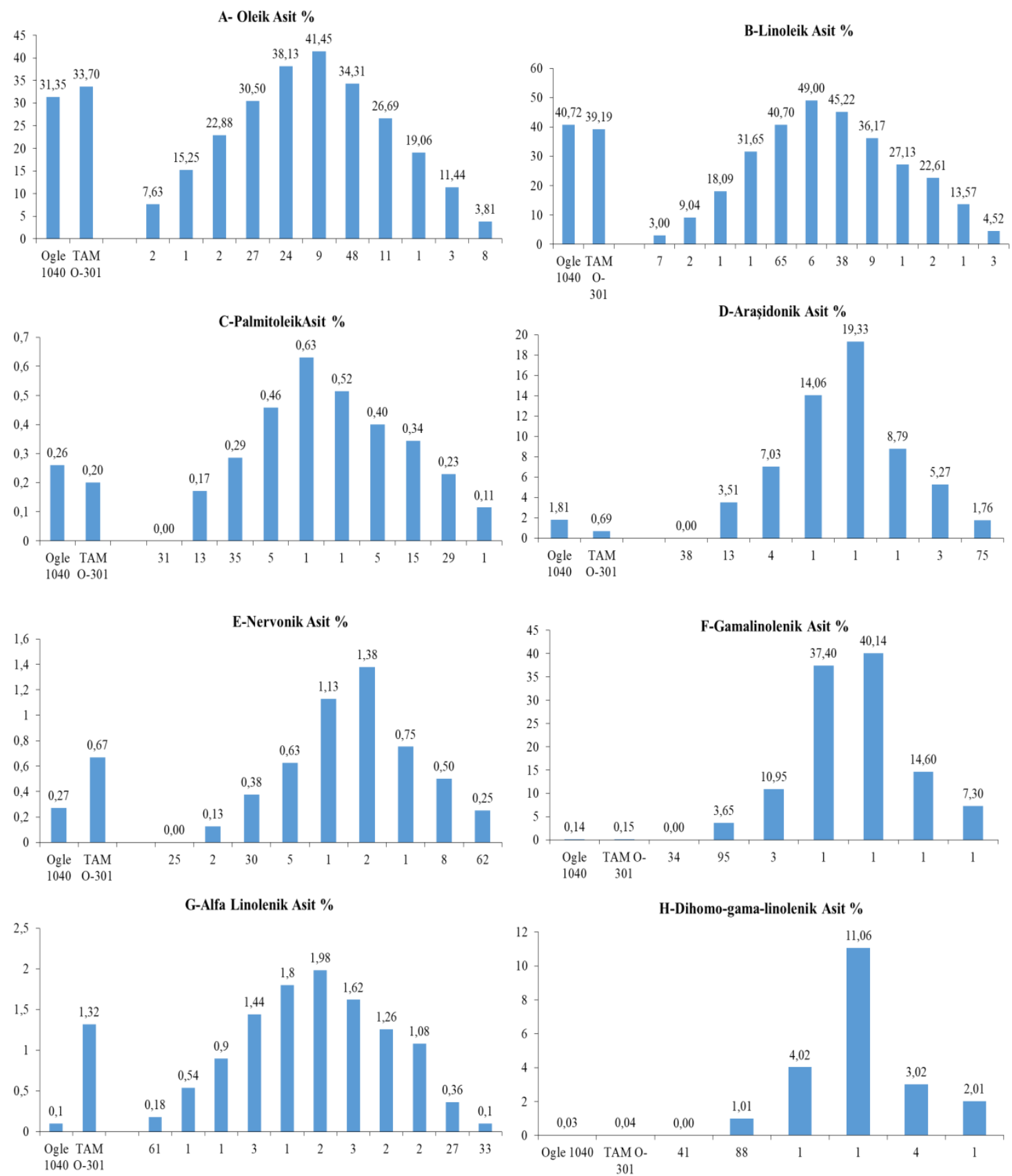

Şekil 2. Ogle1040/Tam 0-301 popülasyonunda doymamış yağ asitlerine ait dağııım.

Ogle1040/Tam 0-301 popülasyonuna ait 136 hat ve ebeveynlere ait ortalama gama-linolenik asit oranı \% 1.09 olarak belirlenmiştir. Alfalinolenik asit analizi sonuçlarına göre, Ogle1040 ebeveyninde alfa-linolenik asidi içeriğinin çok düşük (\% 0.1) öte yandan Tam 0-301 ise \% 1.32 alfa-linolenik asidi içeriğine sahip olduğu saptanmıştır. Popülasyondan 33 genotipin Ogle1040 ile aynı değerlere sahip olduğu görülmüştür. 9 genotip ise Tam 0-301 ebeveyninin sahip olduğu alfa-linolenik asit içeriğinden daha üstün içeriğe sahip olmuştur (Şekil 2). Ogle1040/Tam 0-301 popülasyonuna ait 136 hat ve ebeveynlere ait ortalama alfa-linolenik asit oranı \% 0.26 olarak hesaplanmıştır. Dihomo-gamalinolenik asit analizi sonuçlarına göre, Ogle1040 \% 0.03, Tam 0-301 ise \% 0.04 Dihomo-gama-linolenik asit oranına sahip olmuştur. Popülasyonu oluşturan genotiplerden 41 tanesinde sonuç alınamazken 95 genotipte ise ebeveynlerden geniş bir aralıkta (\% 1.01-11.06) fazla dihomo-gama-linolenik asit içeriğine sahip olduğu tespit edilmiştir (Şekil 2). Ogle1040/Tam 0-301 popülasyonuna ait 136 hat ve ebeveynlere ait ortalama dihomo-gamalinolenik asit oranı \% 0.25 olarak saptanmıştır. Ogle1040/Tam 0-301 popülasyonuna ait 136 hat 
ve ebeveynlere ait doymuş yağ asitleri içerikleri ait histogramlar Şekil 3'de verilmiştir. Palmitik asit analizi sonuçlarına göre, Ogle1040 \% 19.74 palmitik asit oranına sahip olurken, Tam 0-301 ise \% 18.82 oranına sahip olmuştur. Popülasyonu oluşturan genotiplerden OT11, OT42, ОT84 ve OT98 en yüksek palmitik asit oranı değerini almıştır (\% 25.5). Diğer genotipler ise genel olarak \% 2.55 ile \% 22.95 oranında palmitik asit içeriğine sahip olmuşlardır. Ogle1040/Tam 0-301 popülasyonuna ait 136 hat ve ebeveynlere ait ortalama palmitik asit oranı \% 17.81 olarak tespit edilmiştir. Stearik asit analizi sonuçlarına göre, Ogle1040 \% 1.26 stearik asit oranına sahip olurken, Tam 0-301 ise \% 1.86 oranına sahip olmuştur. Popülasyonu oluşturan genotiplerden OT102 ve OT133 en yüksek stearik asit oranı değerini almıştır (\% 3.39). Diğer genotipler ise genel olarak \% 0.40 ile \% 2.90 oranında stearik asite sahip olmuşlardır (Şekil 3). Ogle1040/Tam 0-301 popülasyonuna ait 136 hat ve ebeveynlere ait ortalama stearik asit oranı \% 1.49 olarak saptanmıştır. Lignoserik asit analizi sonuçlarına göre, Ogle1040 \% 0.53 lignoserik asidi oranına sahip olurken, Tam 0-301 ise \% 0.50 oranına sahip olmuştur. Popülasyonu oluşturan genotiplerden OT8 ve OT24 en yüksek oranı almıştır (\% 10). 14 genotipe ait yağ asidi içeriğine rastlanmazken, diğer genotipler ise genel olarak büyük çoğunluğu (111 genotip) \% 0.91 ile \% 8.22 oranında lignoserik asite sahip olmuşlardır (Şekil 3).
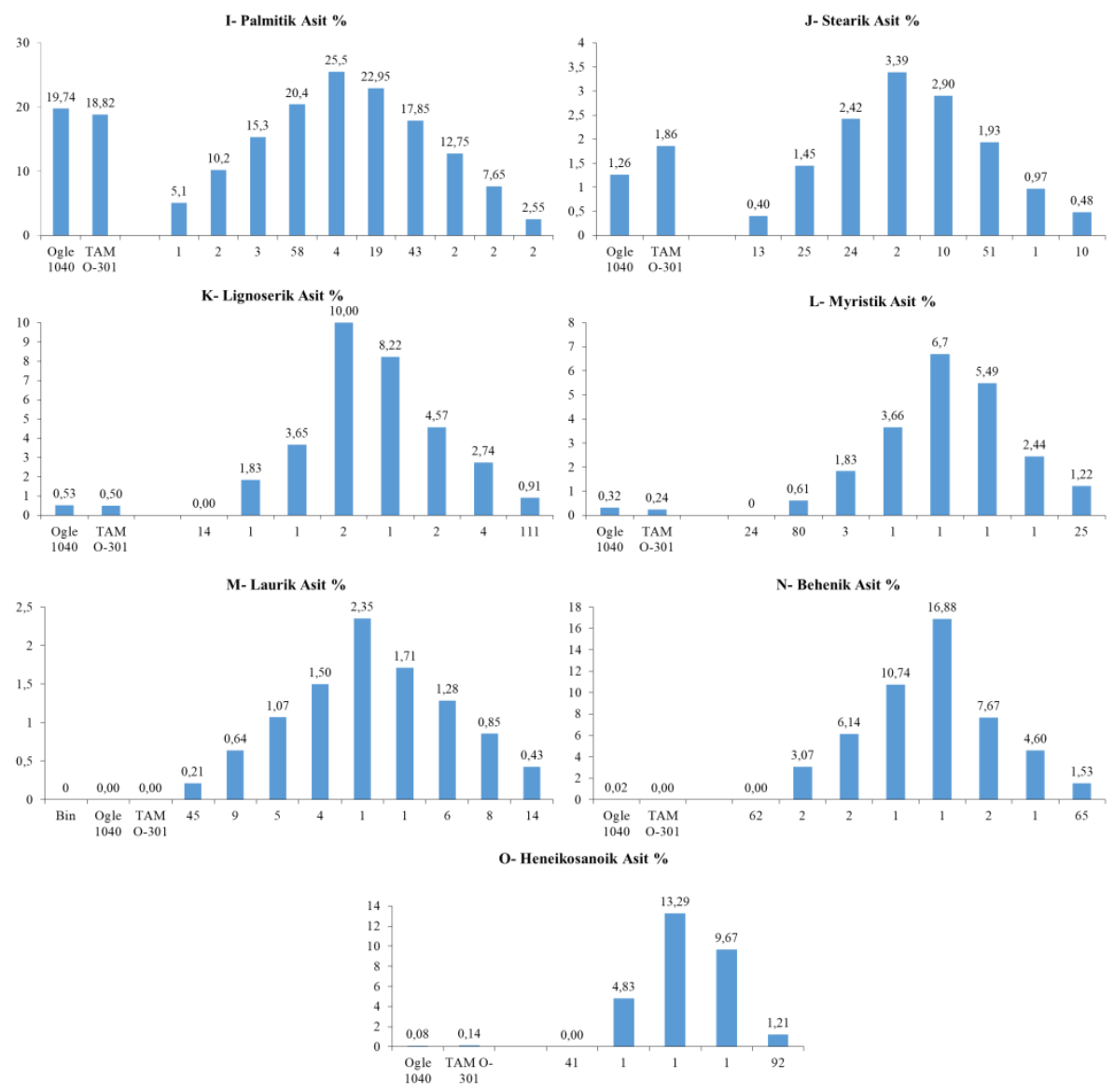

Şekil 3. Ogle1040/ TAM 0-301 popülasyonunda doymuş yağ asitlerine ait dağılım.

Ogle1040/Tam 0-301 popülasyonuna ait 136 hat ve ebeveynlere ait ortalama lignoserik asit oranı \% 0.70 olarak tespit edilmiştir. Miristik asit analizi sonuçlarına göre, Ogle1040 ebeveyninde \% 0.32 miristik asit oranı bulunurken, Tam 0-301 ise \% 0.24 oranına sahip olmuştur. Popülasyonu oluşturan genotiplerden OT14 en yüksek miristik asit oranını almıştır (\% 6.14). Popülasyona ait 24 genotipin yağ asidi içeriği tespit edilemezken, diğer genotipler ise genel olarak
\%0.61 ile \% 5.49 oranında miristik aside sahip olmuşlardır (Şekil 3). Ogle1040/Tam 0-301 popülasyonuna ait 136 hat ve ebeveynlere ait ortalama miristik asit oranı \% 0.52 olarak hesaplanmıştır. Ogle1040 ve Tam 0-301 ebeveynlerinde yağ asitlerinden laurik asit analizi sonucunda, laurik aside rastlanmamıştır. Aynı şekilde popülasyonu oluşturan 43 genotipte ebeveynleri gibi yağ asidi tespit edilmemiştir. Bununlar birlikte geriye kalan 91 genotipe ait laurik 
asit içerikleri ise \% 0.21 ile \% 2.35 arasında bulunmuştur (Şekil 3). Ogle1040/Tam 0-301 popülasyonuna ait 136 hat ve ebeveynlere ait ortalama laurik asit oranı \% 0.28 olarak saptanmıştır. Ogle1040 ebeveynde yapılan behenik asidi analizi sonucu \%0.02 olarak tespit edilmişken, Tam 0-301'de ve diğer 62 genotipte behenik asite rastlanmamıştır. Diğer genotipler ise genel olarak \% 1.53 ile \% 16.88 arasında geniş bir aralıkta behenik asite sahip olmuşlardır. Ogle1040/Tam O301 popülasyonuna ait 136 hat ve ebeveynlere ait ortalama behenik asit oranı \% 0.49 olarak saptanmıştır. Heneikosanoik asit analizi sonuçlarına göre, Ogle1040 \% 0.08 heneikosanoik asit oranına sahip olurken, Tam 0-301 ise \% 0.14 oranına sahip olmuştur. Popülasyonu oluşturan genotiplerden OT9 en yüksek oranı almıştır (\% 13.29), 43 genotipten ise sonuç elde edilememiştir. Diğer genotipler ise genel olarak \% 1.21 ile \% 9.67 oranında heneikosanoik asite sahip olmuşlardır (Şekil 3).Ogle1040/Tam 0-301 popülasyonuna ait 136 hat ve ebeveynlere ait ortalama heneikosanoik asit oranı \% 0.33 olarak tespit edilmiştir.

Araştırmada incelediğimiz tüm yağ asitlerinden elde ettiğimiz bulgular daha önce yapılmış yağ asitleri kompozisyonu çalışmaları ile benzerlik göstermiştir. Batalova ve ark., (2019), yulafta linoleik (\% 36.2-38.7), oleik (\% 33.5-36.7) ve palmitik (\% 15.3-17.8) yağ asitlerinin yulafın temel yağ asitleri olduğunu belirtmişlerdir. Capouchová ve ark., (2021), yulafta en çok bulunan yağ asitlerinin linoleik (\% 37.8-40.0), oleik (\% 34.838.5) ve palmitik (\% 17.1-19.8) asitler olduğunu saptamışlardır. Yulaf tanesinin sahip olduğu yağ içeriğine bakıldığı zaman sağlık açısından önemli olan doymamış yağ asitleri içeriğinin (linoleik ve oleik) yüksek olduğu görülmektedir ve buda yulafı sağlıklı beslenme açısından diğer tahıllardan ayrılmaktadır (Carlson ve ark., 2019). Araştırma sonuçlarında bulduğumuz yulaf tanesinin sahip olduğu yağ asidi kompozisyonlarından \% $1^{\prime}$ in altında olan palmiteloik asit, miristik asit, behenik asit, lignoserik asit ve dihomo-gama-linolenik asitlerin oranları birçok çalışma tarafından benzerlik göstermektedir (Qi ve ark., 2017; Kouřimská ve ark., 2018; Batalova ve ark., 2019). Çalışmamızda elde ettiğimiz bulgulara bakarak yulaf tanesinde bulunan yağ ve bu yağ asitlerine ait yağ asitleri kompozisyonu üzerinde genotipin etkili olduğu bulgularımız ile uyum içerisinde olan birçok çalışma vardır (Doehlert ve ark., 2001; Dhanda, 2011; Krasilnikov ve ark., 2018; Carlson ve ark., 2019; Erbaş Köse ve ark., 2020).

\section{Sonuç ve Öneriler}

Ogle1040/Tam 0-301 yulaf model genetik haritalama popülasyonuna ait 136 hat ve ebeveynlerinin yağ içeriği ve yağ asidi kompozisyonunun belirlendiği çalışmada popülasyona ait yağ içeriği ortalaması \% 2.65 ile 5.89 değerleri arasında varyasyon göstermiştir. Yulafın sahip olduğu yağ içeriğinin yaklaşık \% 75'iini oluşturan doymamış yağ asitlerinden palmitik asit değerleri OT42, ОT98 ve OT84 (\% 28.05, 25.24 ve 24.25) genotiplerinde en yüksek değerleri alırken, oleik asit bakımından OT2, OT16 ve OT63 (\% 41.94, 40.99 ve 39.29) öne çıkmış ve linoleik asit bakımından da OT129, ОT111 ve OT133 (\% 49.74, 46.36 ve 46.01 ) genotipleri diğer hatlardan yüksek değerlere sahip olmuştur. Bu sonuçlara göre, genotipler yağ oranı, stearik asit, oleik asit, nervonik asit, palmiteloik asit, ve laurik asit özelliklerine göre normal dağılıma yakın bir dağılım göstermişler ve bu çalışmada elde edilen bu verilerin kantitatif özelliklerin kromozomlar üzerinde bulunduğu yerlerin tespit edilmesi (QTL) bakımından kullanılabileceği anlaşılmıştır.

Teşekkür: Bu çalışma Hilal KARAKUZULU'nun 2015 yılında tamamlanan "Yulaf Genetik Haritalama Popülasyonu Ogle1040/Tam 0-301'in Yağ İçeriği ve Yağ Asidi Kompozisyonlarının Belirlenmesi" isimli yüksek lisans tezinden üretilmiştir. Yazarlar Kahramanmaraş Sütçü İmam Üniversitesi Bilimsel Araştırma Projeleri Yönetim Birimine de finansal destekleri için teşekkür eder (2013/3-39M YLS).

Çıkar Çatışması Beyanı: Makale yazarları aralarında herhangi bir çıkar çatışması olmadığını beyan ederler.

Araştırmacıların Katkı Oranı Beyan Özeti: Yazarlar makaleye eşit oranda katkı sağlamış olduklarını beyan ederler.

\section{Kaynaklar}

Bağcl, A., Geçgel, Ü., Özcan M. M., Dumlupınar, Z. ve Uslu, N. 2019. Oil contents and fatty acid composition of oat (Avena sativa L.) seed and oils. J. Agroaliment. Processes Technol, 5(4):182186.

Batalova, G., Krasilnikov, V., Popov, V. ve Safonova, E. 2019. Characteristics of the fatty acid composition of naked oats of russian selection. IOP Conference Series: Earth and Environmental Science, (337):012039.

Capouchová, I., Kouřimská, L., Pazderů, K., Škvorová, P., Božik, M., Konvalina, P., Dvořák, P. ve Dvořáček, V. 2021. Fatty acid 
profile of new oat cultivars grown via organic and conventional farming. J Cereal Sci, (98):103180.

Carlson, M. O., Montilla-Bascon, G., Hoekenga, O. A., Tinker, N. A., Poland, J., Baseggio, M. ve Yeats, T. H. 2019. Multivariate genome wide association analyses reveal the genetic basis of seed fatty acid composition in oat (Avena sativa L.). G3: Genes, Genomes, Genetics, 9(9): 29632975.

Dhanda, R. K. 2011. Fatty acid composition in diverse oat germplasm. Master of Science Department of Plant Sciences University of Saskatchewan Saskatoon, Saskatchewan Canada, s. 163.

Doehlert, D. C., McMullen, M. S. ve Hammond, J. J. 2001. Genotypic and environmental effects on grain yield and quality of oat grown in North Dakota. Crop Sci, 41: 10661072.

Dumlupınar, Z., Güngör, H., Dokuyucu, T., Herek, S., Tekin, A. ve Akkaya, A. 2019. Agronomical screening of Ogle1040/TAM 0-301 oat genetic mapping population. Sains Malaysiana, 48(5): 975981.

Erbaş Köse, Ö., Akay, H. ve Mut, Z. 2020. Farklı çevrelerde yetiştirilen yulaf genotiplerinin yağ ve yağ asidi kompozisyonunun belirlenmesi. Anadolu Tarım Bilimleri Dergisi, (35): 396-403.

Iverson, G. L. 2011. Z Scores. "Alınmıştır: Encyclopedia of Clinical Neuropsychology" (eds) Kreutzer, J. S., DeLuca, J., Caplan, B. New York: Springer. S. 203. https://doi.org/10.1007/978-0-38779948-3_1263.

Fan, M., Marshall, W., Daugaard, D. ve Brown, R. C. 2004. Steam activation of chars produced 350 from oat hulls and corn stover. Bioresour. Technol. (93): 103-107.

Frey, K. ve Holland, J. 1999. Nine cycles of recurrent selection for increased groat-oil content in oat. Crop Sci, 39(6):1636-1641.

Gangopadhyay, N., Hossain, M., Rai, D. ve Brunton, N. 2015. A review of extraction and analysis of bioactives in oat and barley and scope for use of novel food processing technologies. Molecules, 20(6):1088410909.

Grundy, M., Fardet, A., Tosh, S., Rich, G. ve Wilde, P. 2018. Processing of oat: the impact on oat's cholesterol lowering effect. Food \& Function, 9(3):1328-1343.

Halima, N. B., Saad, R. B., Khemakhem, B., Fendri, I. ve Abdelkafi, S. 2015. Oat (Avena sativa
L.): oil and nutrient compounds valorization for potential use in industrial applications. J Oleo Sci, 64(9):915-932.

Hoffmann, L. A. 1995. World production and use of oats. "Alınmıştır: The oat crop-production and utilization" (ed) Welch, R.W. Chapman and Hall, London, s. 34-61.

Kan, A. 2015. Characterization of the fatty acid and mineral compositions of selected cereal cultivars from Turkey. Rec. Nat. Prod, 9(1): 124-134.

Kouřimská, L., Sabolová, M., Horčička, P., Rys, S. ve Božik, M. 2018. Lipid content, fatty acid profile, and nutritional value of new oat cultivars. J. Cereal Sci, (84):44-48.

Krasilnikov, V., Batalova, G., Popov, V. ve Sergeyeva, S. 2018. Fatty acid composition of lipids in naked oat grain of domestic varieties. Russ. Agric. Sci, 44(5):406-408.

Mut, Z., Akay, H. ve Erbaş Köse, Ö. D. 2018. Grain yield, quality traits and grain yield stability of local oat cultivars. J. Soil Sci. Plant Nutr, 18(1): 269-281.

Peterson, D. M., Wesenberg, D. M., Burrup, D. E. ve Erickson, C. A. 2005. Relationships among agronomic traits and grain composition in oat genotypes grown in different environments. Crop Sci, (45):1249-1255.

Portyanko, V. A., Hoffman, D. L., Lee, M. ve Holland, J. B. 2001. A linkage map of hexaploid oat based on grass anchor DNA clones and its relationship to other oat maps. Genome, (44):249-265.

Qi, X., Zhu, L., Wang, C., Zhang, H., Wang, L. ve Qian, H. 2017. Development of standard fingerprints of naked oats using chromatography combined with principal component analysis and cluster analysis. J Cereal Sci, (74): 224-230.

Ren, C. Z., Ma, B. L., Burrows, V., Zhou, J., Hu, Y. G., Guo, L., Wei, L., Sha, L. ve Deng, L. 2007. Evaluation of early mature naked oat varieties as a summer-seeded crop in dryland Northern climate regions. Field Crop Res, (103): 248-254

Robert Grob, L. ve Eugene Barry, F. 2004. Gaz Kromatografi Modern Uygulama (4. baskı.) . John Wiley \& Sons, ISBN 0-47122983-0.

Saastamoinen, M., Kumpulainen, J. ve Nummela, S. 1989. Genetic and environmental variation in oil content and fatty acid composition of oats. American Association of Cereal Cehm, 66(4):296-300.

Sangwan, S., Singh, R. ve Tomar, S. K. 2014. Nutritional and functional properties of oats: an update. J. Innov. Biol, (1):003. 
Soxhlet, F. 1879. Die gewichtsanalytische bestimmung des milchfettes, polytechnisches J. (Dingler's), (232):461.

Sterna, V., Zute, S ve Brunava, L. 2016. Oat grain composition and its nutrition benefice. Agric. Agric. Sci. Procedia, (8): 252-256.

Sunulu, S. 2021. Seçilmiş yulaf hatlarında yağ ve yağ asitleri ile bazı kalite özelliklerinin ilişkili haritalama analizleri. KSÜ Fen Bilimleri Enstitüsü Tarla Bitkileri ABD Doktora Tezi s. 163.

Thro, A., Frey, K. ve Hammond E. 1985. Inheritance of palmitic, oleic, linoleic, and linolenic fatty acids in groat oil of oats. Crop Science, 25(1):40-44.

Welch, R. W., Brown, J. C. W. ve Leggett, J. M. 2000. Interspecific and intraspecific variation in grain and groat characteristics of wild oat (Avena) species: very high groat $(1 \rightarrow 3),(1 \rightarrow 4)$ - $\beta$-d-glucan in an Avena atlantica genotype. J Cereal Sci, (31): 271-279.

components of variability. Heredity, 29: 237-245.

Sozen, O., Karadavut, U., Akcura, M. 2017. Determination of the some yield componenets of dry bean (Pahseolus vulgaris L.) genotypes in different environments. International Journal of Agriculture and Environmental Research, 3 (5): 3755-3769.

Sozen, O., Karadavut, U., Ozcelik, H., Bozoglu, H., Akcura, M. 2018. Genotype x Environment interaction of some dry bean (Phaseolus vulgaris L.) genotypes. Legume Research, (41) 2: 189-195.
Sozen, O., Karadavut, U. 2018. Determination of Genotype $x$ Environment Interactions of Some Chickpea (Cicer arietinum L.) Genotypes by Using Diferent Stability Methods. Tarım Bilimleri Dergisi, 24: 431438.

Sozen, O., Karadavut, U. 2019. Statistical Analysis Of Some Characters Affecting Yield In Chickpea Varieties Which Can Be Breeded In Arid Climate Conditions. The Journal of Global Innovations in Agricultural and Social Sciences, 7 (4): 145-149.

Thennarasu, K. 1995. On certain non-parametric procedures for studying genotypeenvironment interactions and yield stability. PhD thesis, PJ School, IARI, New Delhi, India.

Vir, O., Singh, A. K. 2015. Variability and correlation analysis in the germplasm of cluster bean [Cyamopsis tetragonoloba (L.) Taub.] in hyper hot arid climate of Western India. Legume Research-An International Journal, 38 (1), 37-42.

Wricke, G. 1962. Übereine Methode zur Erfassung der ökologischen Streubreite in Feldversuchen. Zeitschrift für Pflanzenzüchtung, 47: 92-96.

Yan, W. 2014. Crop Variety Trials: Data Management and Analysis John Wiley and Sons, 349.

Załuski, D., Tworkowski, J., Krzyżaniak, M., Stolarski, M. J., Kwiatkowski, J. 2020. The Characterization of 10 Spring Camelina Genotypes Grown in Environmental Conditions in North-Eastern Poland. Agronomy, 10 (1), 64, 1-13. 